\title{
THE ROLE OF SOCIAL MEDIA IN ARAB SPRING
}

\author{
Kevser Zeynep MERAL \\ Bahçeşehir Üniversitesi, Türkiye \\ kevserzeynep.meral@bahcesehir.edu.tr \\ https://orcid.org/0000-0002-2514-8744 \\ Yurdagül MERAL \\ İstanbul Medipol Üniversitesi, Türkiye \\ ymeral@medipol.edu.tr \\ https://orcid.org/0000-0001-9244-1994
}

\begin{abstract}
The 'Arab Spring' that started in Tunisia at the end of 2010 continued until the beginning of 2011 with Egypt and other Arab countries. The "Arab Spring", which led to power changes in Tunisia, Egypt, Libya and Yemen, was prevented by spending billions of dollars and committing reforms in other countries such as Saudi Arabia and Morocco in the region. The uprising opponents communicated through social media, organized and made their voices heard via social media. The purpose of this study is to explain the impact of social media affect on the 'Arab Spring' movement. Social media enabled the world to follow activists, but at the same time also enabled the participants and the activists to communicate and brought them together. In this study, where literature review was used as a research method, the results of the literature review focused on the use of social media tools in the example of Egypt indicate that the use of Facebook predominantly affects the process called "Arab Spring" in Egypt.
\end{abstract}

Keywords: Social Media, Facebook, Twitter, Digital Communication.

\section{SOSYAL MEDYANIN ARAP BAHARINDAKİ ROLÜ}

\section{Öz}

Tunus'da 2010 sonunda başlayan 'Arap Baharı' Misır ve diğer Arap ülkeleri ile 2011'in başlangıcına kadar devam etti. Tunus, Mısır, Libya ve Yemen'de iktidar değişikliklerine yol açan 'Arap Baharı', bölgedeki Suudi Arabistan, Fas gibi diğer ülkelerde ise milyarlarca dolar harcanarak ve reform taahhüdünde bulunularak ayaklanmalar önlenebilmiştir. Ayaklanan muhalifler sosyal medya üzerinden iletişim kurarak, örgütlenmiş ve seslerini duyurmuştur. Bu çalışmanın amacı, sosyal medya etkisinin 'Arap Baharı' hareketi üzerindeki etkisini açıklamaktır. Sosyal medya, sadece dünyanın aktivitistleri takip etmesini değil, aynı zamanda katılımcıların ve aktivistlerin haberleşmesini sağlayarak onları bir araya getirdi. Sosyal medya aynı zamanda bu süreçte insanların birbirleriyle iletişimini de sağladı. Araştırma metodu olarak literatür taraması kullanılan bu çalışmada Mısır örneğinde, sosyal medya araçlarının kullanımı odaklı literatür taraması sonuçları, ağırlıklı olarak Facebook kullanımının, Mısır'da 'Arap Baharı' olarak adlandırılan süreci etkilediğini ifade etmektedir.

Anahtar Kelimeler: Sosyal Medya, Facebook, Twitter, Dijital İletişim. 


\section{INTRODUCTION}

The 'Arab Spring' starting in Tunisia, in December 2010 till beginning of 2011 covering North Africa to Middle East was followed up by the world via social media. "Arab Spring" started in Tunisa, continued with Egypt, where revolt ended with Mobarak's resignation where the activists used new media, social media tools during the revolution, sharing it instantly among them and with the world.

Intra-state conflicts have killed millions of people (Collier et al., 2004). The main reason of 'Arab Spring' in Egypt is economic. The economic growth of Mobarak's goverment implementation for more privatization in 2000 only increased the income of the rich and the unemployment rate even increased among young people (Mena Development Report, 2004). The primary reason for the protestors to succeed was economic (URL-35). The revolt starting with Tunisia followed by Egypt, against the poverty, inequality, corruption, unemployment and injustice effected the other Arab countries as well. Arab Spring starting in Tunisia and Egypt in December 2010 and January 2011 followed in Libya, Bahrain, Syria and Yemen (URL-31).

Secondly, food price increase also affected Egypt. More expensive food is also one of the main reasons for Arab Spring (Bellemare, 2015) as well. In 2010 cereal prices has increased sharply all over the world due to weather conditions in other words actually climate change was one of the reasons of Arab Spring (Johnstone and Mazo, 2011). Wheat price has increased 70 percent. Wheat is the core of bread and bread is the main food of low income families. If bread price increases, poor people's main food, leads to hunger, hunger leads to revolt (Laipson, 2011).

Thirdly, political reasons also affected Egypt. Political stability is not independent from income. Instability costs are very important. Researches show that, instability is one of the main reasons of revolt because nearly $50 \%$ of countries where instability exist had civil conflicts for the past ten years (Collier et al., 2004). Furthermore, demographic reasons also affected the Arap Spring in Egypt. The young population is a problem in Middle East because the young population's rate is high and unemployment is a major problem for the young population. Whereelse the old population is a problem in West because the elderly, retired, old aged population rate is higher than the young population in West. The gap between the older population and the younger population is a problem. The unemployed young population moving from villages to cities was another factor (Kepel, 2002), the age group between 2125 of young Egyptians who came out to the Tahrir Square in Cairo in January 2011, as noted by J. Goldstone, "Most major revolutions...- [including and] most twentieth-century revolutions in developing countries- have occurred where exceptionally large youth bulges were present" (URL-23).

Another important factor affecting Egypt is the geographic and geopolitic reasons, unstability in neighbors can also increase domestic instability as well, through economic and social stress and through civil war spread from the neighbour country (Ades and Chua, 1997).

Instability in a neighbor country is a major threat as well. The cost of trade increases due to the risk in neighborhood. People running away from the instable country is a risk including health problems as well as the financial burden of taking care of them. Refugee flows increase causing health problems to the region. There are researches about the financial cost of instability, like neighboring country's instability decrease growth rate by 0.5 percent per year (World Bank Policy Research Report, 2003).

Neighbour countries' state also affect the countries. At an international level, other Arab countries except Saudi Arabia and Qatar had the risk of an attempt 2011 like Egypt. Both Tunisa and Egypt are two of the most homogeneous countries in the Arab world. Egypt, which has a long history as a populous and urbanized country, is not divided by tribe, and Muslims in Tunisia and Egypt are overwhelmingly Sunni.

Furthermore, what differentiated Egypt, from other Arab countries is that Egypt was not like the other countries, it was not like tribes of Libya, the army was different, much more organized, army was an important factor. Education level was higher than the other Arab countries. As said "...given its enormous demographic weight and political influence in the Arab world, as Egypt goes, so will go the region". Egypt revolution had a great impact all over the world especially in the other Arab countries, scared of losing their power, the authocrat monarchs have shared their wealth with public. Kuwait budgeted $\$ 70$ billion for state employees (Collier et al., 2004), and $\$ 3,650$ per person cash totalling 
approximately 4 billion dollars plus free food till 2011 March. Bahrain distributed cash to families (Smith, 2011). Saudi Arabia increased salaries 40 percent, $\$ 130$ billion cash was spent additionally for housing investment and to religious organizations. At the same time 10 billion dollars to Bahrain and 10 billion dollars to Oman was to be paid and 8 billion dollars to Egypt, to help the neighbour countries to stabilize their political status (URL-16). Saudi Arabia, invested in Egypt for billions to stabilize the country (URL-22). This revolution although in a Muslim country, was not like the Islamic Revolution in Iran. The Tahrir Square 'revolution' was differed from Islamic Iran revolution as; because they were non-violent and non-nationalistic, the common aim was to bring bringing Mubarak down (Smith, 2011). In other words, the main principle was 'civil democratic state' not the Islamic Law like Iran. Egypt is considered as a "civil democratic state", Islamic Law is accepted as legislation (Al-Masry al-Youm, 2011). Of course the most important difference between Egypt's revolution and previous revolution was using "social media".

\section{SOCIAL MEDIA AND EGYPT}

“Twitter doesn't cause revolutions, but revolutions are tweeted." (McAdam, Tarrow and Tilly, 2001). The meaning of the word 'occupy' has changed, with Tahrir Square, Wall Street and others. "Occupy Wall Street" movement argued that their goal was to expose the richest $\% 1$ wrote the global economy rules which was a foreclosure to their future (URL-25).

Development of social media-via internet has changed our lives. The news are not followed from the newspapers published a day earlier. Especially the young generation is following everything via social media. New technology in communication, increased new social media tools like (SMS), networking sites, blogs etc. for social movements (Della and Mosca, 2005), (Langman, 2005), (O'Lear, 1999), (Wasserman, 2007).

Facebook active account holders number has already exceeded 1 billion, twitter nearly 225 million as of first quarter of 2014. With Internet and like Facebook, Twitter platforms changed everything in social connectivity (Khamis \& Vaughn, 2011), (Radsch, 2008). Zuckerman (URL-38) claimed that nonpolitical platforms are better because they can avoid being targeted.

Social media users do not only use it for following up the news, mainly they share everything with their network via their accounts. One billion active facebook users, by sharing their photos in every occasion, social events, night outs, checking via four squares, instagram photos are living in a virtual world, keeping in touch with their acquantices virtually. Facebook, with four million users in Egypt by late 2010 (Khamis \& Vaugh, 2011). Users numbers have increased to 40 million as of February 2019, which is approximately 38,9 percent of the population (URL-29).

In other words using social media is a part of our daily lives and not only political. There are different views about using social media, whether it is shattering or supportive authority governments. Internet is considered as disruptive by some people (Aday et al., 2010), (Howard, 2010) wherelse on the contrary some think that Internet supports authoritarian regimes (Morozov, 2011). With the increase of using social media via internet actually Internet service disruptions are nothing new (URL-5), (URL-6), (URL33), (URL-36), (URL-37). In Singapore as well, it is claimed that using social media (Facebook) platforms, along with traditional media were used to organize a student protest in Singapore (Skoric et al., 2011).

Social media has a an important role in Egypt. The government has invested in new communication technologies. This investment on new communication technologies decread the prices with easy access. Affordable and easy access to social media was now available for Egyptians because the state expanded Egypt's information technology to achieve socioeconomic development. State provided free Internet access, cheap computers, and extended Internet centers in 1999 (Hamdy, 2009) which increased number of internet and social media users, especially Facebook users number was higher in Egypt, nearly eighty percent of social media users had Facebook accounts (URL-11). 
When first launched, only English blogs were possible, however with the Arabic language internet, in 2009 Arabic software, Arabic blog numbers increased in 2009. Arabic software encouraged the creation of more blogs in Arabic with domestic local native Arabic speakers (Hamdy, 2009).

Tüfekci and Wilson (2012) claimed that more than a quarter heard the protests on Facebook first, and reposted te photos and videos by using Facebook. Not only was the Arabic version of Internet the only factor. Investment in communication technologies, to use social media via mobile was much more cheaper, blogs increased and activists started using other communication tools of social media like Facebook, Flicker, Twitter, and cellular phones. The initial support via social media Facebook, was in April, 2008, facebook supporters for textile workers strike were 70 thousand but was suppressed by state security (Hamdy, 2009). Egypt's Tahrir Square protests, were not followed via classical media. Social media was used massively and the world followed the protests via social media. First via Twitter, then followed by traditional media (Lotan et al., 2011). Parallel with the increase in social media users, activism increased in Egypt (Howard \& Hussain, 2011).

"Egyptian revolution", the protests between January 25 and February 11, 2011, led to Egyptian President Hosni Mubarak's resignation show that large organizations via social media affect on social movements (Eltantawy and Wiest, 2011).

The officials tried to black-out internet during the revolt in Egypt as well. They refused to admit the blackout but 23 million Internet users disappeared from Internet, on January 27, 2011. The specific blackouts in Egypt case in the study of (Dainotti et al., 2009), were gathered from several commercial Internet measurement companies from their data analyses during and following the outages (URL-32), (URL-7), Cowie, J. (URL-8), Cowie, J. (URL-9), (URL-19), (URL-20), (URL-21), (URL-34). A detailed report of the internet blackout in Egypt is given during the revolt days especially on January 27 around 22:32:00 GMT and lasted for more than five days (Dainotti et al. 2011:1-18). The government trying to blackout the internet succeded in doing so but this did not stop the young Egyptians to protest, till the resignation of Mobarak.

The state wanted to shut internet completely and ordered although the state officials did not accept blocking social media, Twitter was blocked on 25 January (URL-17), (URL-26).

\section{THE MOST POPULAR SOCIAL MEDIA PAGES OF EGYPT REVOLUTION}

\section{The Facebook Group "We Are All Khalid Said"}

When Tunisian uprising started in December 2010, at first a campaign followed by protest (January 25, 2011) inviting "We are All Khaled Said" page on Facebook (URL-4). The Facebook group "We are all Khalid Said" (URL-15) was created for the young man named Khalid Said who was killed by the police. The young man was an owner of an Internet Cafe and was killed because refused to give bribery to policemen, he was beaten till death and left in the Street. Police collected the body and his family was reportedly told that he died after choking (URL-10).

Although the facebook group page was mainly about the death of the young man at the beginning, it became a center of political discussion, Egyptians opponents of Mobarek, the group nember expanded. Said's death become a symbol, internet websites were with his disfigured face, everybody including human-rights activists and ElBaradei, were in the streets of their outrage. Egyptian policemen charged over Khaled Said death in 2010.

\section{"EIBaradei for Presidency" and EIBaradei’s Personal Facebook Page}

ElBaradei was who used Internet to communicate and to share information with his followers. As complements to ElBaradei's personal Facebook page (URL-14) and his followers of Twitter account, and other supporters formed pro- ElBaradei Facebook pages (URL-12). He was of one of the opponents of Mobarek. He said to a newspaper that change was ineviteble in Egypt (URL-30). 


\section{Omar Afifi (Facebook, Twitter, YouTube)}

Omar Afifi, a former Egyptian police officer, who wrote a book about avoiding police brutality. However his book was banned went to United States and continued his advices via social media technologies through YouTube videos, Facebook, and Twitter in US. Afifi posted all the details about gathering places, what to wear during Tunisian protest, and posted Afifi's videos of peaceful protest (URL-1), (URL-2), (URL-3). Young Egyptians were following new media, with precautions given in media, they were very good at using all kind of instructions via youtube, facebook etc.

\section{Nawara Negm (blogger)}

Egyptian female activist and blogger Nawara Negm posted a video of an Egyptian actress of encouragement for Tunisians on January 17, 2011. She also shared Negm information and cell phone numbers, asking Egyptians to send supporting messages to Tunisians during the protests (URL-24). She was an female activist. She shared everything with her followers including phone number to support the activits. Negm posted an invitation to her followers to join the activits as "Be noble and demonstrate on January 25,". She shared a YouTube video and said, "Do you see this girl? She is going to demonstrate." She invited her followers and asked them to invite friends or other Egyptians to join and wrote: "walk . .. walk in the street. Walk walk walk ... and talk talk talk ... and sing sing national songs, sing Beladi Beladi [my country my country]", and advised them to take pictures, to share them via Twitter by sending tweets or share via blogs (URL-24).

\section{“January 25" Facebook Page}

Three teenagers, created the final, victory page is called "January 25" Page: on January 16 (URL-13). The "January 25 " had a video, addressing the public, explaining the achievements of Tunisia, and that would be following them in Egypt (URL-13). The activists addressed millions of people via these pages all at one time by one post to all over Egypt, of which might be the most important feature of new media, sharing information with millions at an instant, might have helped succeed the activists in Egypt to end the authocratic Mobarak era. Social media's affect was also very impressive, although the government tried to stop the protests by suppressing the media, social media (Facebook) united the Egyptians (f, 2011). Blocking communications including main media (URL-27), commercial internet measurement companies technical data analyses (URL-7), (URL-19), (URL-288), following the protests, President Hosni Mubarak resigned, military command took over on February 11 (Daniotti et al. 2011), they succeeded to end the 30-years of Mobarak regime after the resignation of Mobarak.

\section{CONCLUSION}

The main difference during 'Arab Spring' movement was that social media tools were used. Bhuiyan (2011) study show that there were approximately 20 million social media users since 2009 and that social media tools had a critical role in Arab Spring. When activists in Egypt during Arab Spring were connected with each other by using social media, mainly via facebook although the government tried to block could not stop social media. Activists shared events via social media with the World. Although supported by West, had the power and the biggest army in the region, the uprising ended with Mobarak's resignation after 30 years of Mobarak regime.

Today, social media is much more effective with 4,388 billion internet users, and 3,484 billion social media users worldwide according to Global Digital Report (URL-18). Social media users are increasing 9,1 percent year by year. The affect of social media is increasing as well, and new tools are also emerging. Future researchers must be aware of new social media tools as well, like TikTok which has already reached worldwide 500 million active user in less than three years according to datareportal. Tiktok is a short videosharing platform, developed by ByteDance and increasing rate is more than facebook. Social media's effect must be taken into consideration in all aspects, and future research must also cover cross-national view as well, as results might be different depending on the nation. 


\section{REFERENCES}

Aday, S., Farrell, H., Lynch, M., Sides, J., Kelly, J., \& Zuckerman, E. (2010). Blogs and bullets: New media in contentious politics. United States Institute of Peace, 65, 1-31.

Ades, A., \& Chua, H. B. (1997). Thy neighbor's curse: regional instability and economic growth. Journal of Economic Growth, 2(3), 279-304.

Al-Masry al-Youm. (2011). Newspaper, 24.08.2011.

Bellemare, M. F. (2015). Rising food prices, food price volatility, and social unrest. american Journal of agricultural economics, 97(1), 1-21.

Bhuiyan, S. I., 2011. "Social Medya and Its Effectiveness in the Political Reform Movement in Egypt, Middle East Media Educator", 1(1), ss. 12-20.

Collier, P., Hoeffler, A., \& Söderbom, M. (2004). On the duration of civil war. Journal of peace research, 41(3), 253-273.

Dainotti, A., Squarcella, C., Aben, E., Claffy, K. C., Chiesa, M., Russo, M., \& Pescapé, A. (2011, November). Analysis of country-wide internet outages caused by censorship. In Proceedings of the 2011 ACM SIGCOMM conference on Internet measurement conference (pp. 1-18).

Della Porta, D., \& Mosca, L. (2005). Global-net for global movements? A network of networks for a movement of movements. Journal of public policy, 165-190.

Eltantawy, N., \& Wiest, J. B. (2011). The Arab spring| Social media in the Egyptian revolution: reconsidering resource mobilization theory. International journal of communication, 5, 18.

Hamdy, N. (2009). Arab citizen journalism in action: Challenging mainstream media, authorities and media laws. Westminster Papers in Communication \& Culture, 6(1).

Howard, P. N. (2010). The digital origins of dictatorship and democracy: Information technology and political Islam. Oxford University Press.

Howard, P. N., \& Hussain, M. M. (2011). The upheavals in Egypt and Tunisia: The role of digital media. Journal of democracy, 22(3), 35-48.

Kepel, G. (2002). Jihad: The trail of political Islam. Harvard University Press.

Khamis, S., \& Vaughn, K. (2011). Cyberactivism in the Egyptian revolution: How civic engagement and citizen journalism tilted the balance. Arab Media and Society, 14(3), 1-25.

Johnstone, S., \& Mazo, J. (2011). Global warming and the Arab Spring. Survival, 53(2), 11-17.

Laipson, E. (2011). Seismic Shift: Understanding Change in the Middle East. Washington DC: The Henry L. Stimson Center.

Langman, L. (2005). From virtual public spheres to global justice: A critical theory of internetworked social movements. Sociological theory, 23(1), 42-74.

Lotan, G., Graeff, E., Ananny, M., Gaffney, D., \& Pearce, I. (2011). The Arab Spring| the revolutions were tweeted: Information flows during the 2011 Tunisian and Egyptian revolutions. International journal of communication, 5,31 .

McAdam, D., Tarrow, S., \& Tilly, C. (2003). Dynamics of contention. Social Movement Studies, 2(1), 99-102.

MENA Development Report (Washington, DC: The World Bank, 2004), Review of Middle East Economics and Finance, 2(3), 219-220.

Morozov, E. (2012). The net delusion: The dark side of Internet freedom. PublicAffairs.

O'lear, S. (1999). Networks of engagement: Electronic communication and grassroots environmental activism in Kaliningrad. Geografiska Annaler: Series B, Human Geography, 81(3), 165-178. 
Radsch, C. (2008). Core to commonplace: The evolution of Egypt's blogosphere. Arab Media \& Society, 6, 1-14.

Skoric, M. M., Poor, N. D., Liao, Y., \& Tang, S. W. H. (2011, January). Online organization of an offline protest: From social to traditional media and back. In 2011 44th Hawaii International Conference on System Sciences (pp. 1-8). IEEE.

Smith, B. (2011). The Arab Uprisings. House of Commons Library, Research Paper, 11(73), 11.

Tufekci, Z., \& Wilson, C. (2012). Social media and the decision to participate in political protest: Observations from Tahrir Square. Journal of communication, 62(2), 363-379.

Wasserman, H. (2007). "Is a new worldwide Web possible? An explorative comparison of the use of ICTs by two South African social movements," African Studies Review, 50 (2007-1), 109-131.

World Bank. (2003). Breaking the conflict trap: Civil war and development policy. World Bank Policy Research Report.

\section{ELECTRONIC SOURCES}

URL-1: Afifi, O. (2011a). January 14 Tunisian Freedom Day \& our date is January 25. [YouTube video]. http://www.youtube.com/watch?v=gdJQRz0BtU8\&feature=related, Access Date: 13.08.2014.

URL-2: Afifi, O. (2011b). General instructions on peaceful protests: Part I. [YouTube video]. http://www.youtube.com/watch?v=ujtIdyfjgWU, Access Date: 13.08.2014.

URL-3: Afifi, O. (2011c). General instructions on continued peaceful protests: Part II. [YouTube video]. "http://www.youtube.com/watch?v=YYheiPStXtY\&feature=related, Access Date: 13.08.2014.

URL-4: Baker, A. (2011). How Egypt's opposition got a more youthful mojo. http://www.time.com/time/world/article/0,8599,2045446,00.html, Access Date: 13.08.2014.

URL-5: Burris, J. (2010). 29 November 2010. Comcast: Internet service restored after regional outage. "http://articles.baltimoresun.com/2010-11-29/news/bs-md-comcast-20101128 1 outage-internetservice-disruptions Access Date: 13.08.2014.

URL-6: Cowie, J. (2009). Strange Changes in Iranian Transit. http://www.renesys.com/2009/06/strange-changes-in-iranian-int/, Access Date: 13.Aug.2014.

URL-7: Cowie, J. (2011/a). 27 January 2011. Egypt Leaves the Internet. http://www.renesys.com/2011/01/egypt-leaves-the-internet/ Access Date: 13.08.2014.

URL-8: Cowie, J. (2011/b). 18 February 2011. Libyan Disconnect. http://www.renesys.com/2011/02/libyan-disconnect-1/, Access Date: 13.08.2014.

URL-9: Cowie, J. (2011/c). 05 March 2011. What Libya Learned from Egypt. http://www.renesys.com/2011/03/what-libya-learned-from-egypt/, Access Date: 13.08.2014.

URL-10: El Amrani, I. (2010, June 14). The murder of Khaled Said. Arabist. http://www.arabist.net/blog/2010/6/14/the-murder-of-khaled-said.html, Access Date: 13.08.2014.

URL-11: Emarketer.com. (2014). Facebook Usage High in Egypt and Jordan. https://www.emarketer.com/Article/Facebook-Usage-High-Egypt-

Jordan/1010709\#: : :text $=$ In $\% 20$ addition $\% 2 \mathrm{C} \% 20 \mathrm{we} \% 20$ expect $\% 20185.0$, to $\% 20$ use $\% 20$ Facebook $\% 2$ 0in\%202014. Access Date: 06.09.2020

URL-12: Facebook page. (2011). ElBaradei for Presidency. "http://www.facebook.com/m.elbaradei2011, Access Date: 13.08.2014.

URL-13: Facebook page. (2011). January 25: the day of revolution over torture, poverty, corruption \& unemployment [translated from Arabic]. "http://www.facebook.com/\#!/Yom.Elsawra.25.January?sk=app 4949752878, Access Date: 13.08.2014. 
URL-14: Facebook page. (2011). Mohamed ElBaradei.

http://www.facebook.com/\#!/group.php?gid=184655341853,Access Date: 13.08.2014.

URL-15: Facebook page. (2011). We are all Khaled Said. "http://www.facebook.com/home.php\#!/elshaheeed.co.uk, Access Date: 13.08.2014.

URL-16: Financial Times. (2013). 10. July. 2013. https://www.ft.com/content/7e066bdc-e8a2-11e28e9e-00144feabdc0. Access Date: 06.09.2020.

URL-17: Garret, S. (2011). We can confirm that Twitter was blocked in Egypt around 8 a.m PT today. "https://twitter.com/twittercomms/status/30063209247408128, Access Date: 13.08.2014.

URL-18: Global Digital Report. (2019). https://hootsuite.com/pages/digital-in-2019, Access Date: 25.01.2020.

URL-19: Labovitz, C. (2011a). 02 February 2011. Egypt returns to the Internet. "http://www.arbornetworks.com/asert/2011/02/egypt-returns-to-the-internet/ Access Date: 13.08.2014.

URL-20: Labovitz, C. (2011b). 20 February 2011. Middle East Internet Scorecard. "http://www.arbornetworks.com/asert/2011/02/middle-east-internet-scorecard-february-12-20/ Access Date: 13.08.2014.

URL-21: Labovitz, C. (2011c). 28 January 2011. Egypt Loses the Internet. http://monkey.org/ labovit/blog/viewpage.php?page=egypt_loses_internet Access Date: 13.Aug 2014.

URL-22: Mawji, O. (2016). Saudi Arabia Comes to the Rescue of the Egyptian Economy. https://www.geopoliticalmonitor.com/saudi-arabia-comes-to-the-rescue-of-the-egyptian-economy/ , Access Date: 15.01.2020.

URL-23: National Research University, Higher School of Economics, Laboratory for Comparative Social Research. (2013). 2011 Egyptian Revolution: A Demographic Structural Analysis, October 2013. http://lcsr.hse.ru/en/news/98399560.html, Access Date: 15.08.2014.

URL-24: Negm, N. (2011). 01 January 2011. Tahyees front blog. "http://tahyyes.blogspot.com/2011_01_01_archive.html., Access Date: 15.08.2014.

URL-25: OccupyWallStreet.org. (2011) “http://occupywallst.org/about/ Access Date: 13.08.2014.

URL-26: Reuters. (2011) Facebook says has seen drop in traffic from Egypt. "http://www.reuters.com/article/2011/01/27/ facebook-egypt-idUSN2727880720110127, Access Date: 13.08.2014.

URL-27: Reuters. (2011). 26 January 2011. Egypt govt denies disrupting websites - cabinet. http://www.reuters.com/article/2011/01/26/egypt-web-idUSLDE70P28720110126 Access Date: 13.08.2014.

URL-28: RIPE. (2011). Analysis of Egyptian Internet outage 27th January - 2nd February 2011. https://stat.ripe.net/events/egypt Access Date: 13.08.2014.

URL-29: Statistics. (2019). https://napoleoncat.com/stats/facebook-users-in-egypt/2019/02 , Access Date: 15.01.2020.

URL-30: The Guardian. (2011). $30 \quad 3011$. https://www.theguardian.com/world/2011/jan/30/egypt-protests-mohammed-elbaradei Access Date: 13.08.2014.

URL-31: The New York Times. (2011). 12 February 2011. https://www.nytimes.com/2011/02/12/world/middleeast/12revolution.html. Access Date: 06.09.2020.

URL-32: Toonk, A. (2011). Internet in Egypt offline. Border Gateway Protocol Monitoring, 28. "http://bgpmon.net/?p=450,\%2520January\%25202011 Access Date: 13.08.2014.

URL-33: Underwood, T. (2006). 22 January 2006. Con-Ed Steals the 'Net. "http://www.renesys.com/2006/01/coned-steals-the-net/ Access Date: 13.08.2014. 
URL-34: Van Beijnum, I. (2011). How Egypt did (and your government could) shut down the Internet. Ars Technica. http://arstechnica.com/tech-policy/2011/01/how-egypt-or-how-yourgovernment-could-shut-down-the-internet/ Access Date: 13.08.2014.

URL-35: White, B. J. (2011). "Arab Spring: in foreign aid to Egypt and Tunisia, questions loom"e, International Business Times, 17 June 2011. "http://www.ibtimes.com/arab-spring-foreign-aid-egypttunisia-questions-loom-291513 Access Date: 13.08.2014.

URL-36: Zmijewski, E. (2008/b). 10 August 2008. Georgia Clings to the 'Net. "http://www.renesys.com/2008/08/georgia-clings-to-the-net/ Access Date: 13.08.2014.

URL-37: Zmijewski, E. (2008/c). 30 January 2008. Mediterranean cable break - Part II. "http://www.renesys.com/2008/01/mediterranean-cable-break-part-1/ Access Date: 13.08.2014.

URL-38: Zuckerman, E. (2008). The cute cat theory. My heart's in Accra. http://www.ethanzuckerman.com/blog/2008/03/08/the-cute-cat-theory-talk-at-etech/

Date:13.08.2014. 